\title{
Horror i troska. Narracje antropocenu dla dzieci na przykładzie Miasta Złotej Daniela Chmielewskiego i Magdy Rucińskiej
}

\section{Abstrakt:}

Autorka artykułu, interpretując książkę Miasto Złotej Daniela Chmielewskiego i Magdy Rucińskiej (2018), nazwaną przez twórców horrorem urbanistycznym, podejmuje próbę rozszerzenia tej kategorii o cechy horroru ekologicznego. Odwołując się do koncepcji antropocenu, humanistyki ekologicznej oraz ekokrytyki, stara się ustalić, na ile postulaty sformułowane przez te idee realizowane są w interpretowanym tekście. Okazuje się, że ich obecność nie tylko w interesujący sposób modyfikuje wyznaczniki gatunkowe horroru, ale przede wszystkim czyni z analizowanej książki minitraktat o wychowaniu do wspólnoty.

Słowa kluczowe:

antropocen, Daniel Chmielewski, horror ekologiczny, horror urbanistyczny, humanistyka ekologiczna, ekokrytyka, Magda Rucińska, Miasto Złotej, scenariusze przyszłości

\section{Horror and Concern: Anthropocene Narratives for Children} on the Example of Miasto Złotej by Daniel Chmielewski and Magda Rucińska

\section{Abstract:}

The article presents an interpretation of the book by Daniel Chmielewski and Magda Rucińska, Miasto Złotej [Inner City] (2018), classified by the authors as an urban horror story. The author of the paper attempts to expand this category with elements of the eco-horror genre. The study is supplemented by the concept of Anthropocene, as well as an approach that integrates ecological humanities and ecocriticism. It is aimed to determine to what extent the postulates related to those

* Małgorzata Wójcik-Dudek - dr hab., pracuje w Instytucie Literaturoznawstwa na Wydziale Humanistycznym Uniwersytetu Śląskiego w Katowicach. Jej zainteresowania badawcze obejmują dydaktykę literatury oraz literaturę dla dzieci i młodzieży. Kontakt: malgorzata.wojcik-dudek@us.edu.pl. 
notions are implemented in the analysed book. The author of the article proves that not only does their presence modify generic conventions of horror, but most of all it transforms the book into a small treaty on community education.

Key words:

Anthropocene, Daniel Chmielewski, eco-horror story, urban horror story, ecological humanities, ecocriticism, Magda Rucińska, Miasto Złotej, scenarios for the future

A nita Has-Tokarz (2010), autorka fundamentalnej pracy poświęconej estetyce horroru, przekonuje, że sam termin „horror” został zaczerpnięty z języka angielskiego dla „sygnowania zjawisk filmowych i literackich posługujących się treściami i rekwizytornią, które wzbudzają silne emocje, w tym przerażenie" (s. 50). Badaczka, uszczegóławiając definicję, rozbudowuje przede wszystkim dwa jej elementy, tj. treść oraz rekwizytornię, proponując następujące rozumienie pojęcia:

[...] horror jest formułą artystyczną uwarunkowaną zindywidualizowanym czynnikiem estetycznym doznawania grozy, którego realizacja dokonuje się poprzez zastosowanie - na poziomie tekstu - określonych motywów, stylistyczno-językowych środków narracyjnych, efektów dramaturgicznych (suspens, stopniowanie potencjału napięcia fabularnego) oraz kompozycyjnych (ambiwalentna struktura świata przedstawionego) podporządkowanych ewokacji atmosfery lęku i grozy u odbiorcy (s. 50).

Katarzyna Slany (2016) w znakomitej książce Groza w literaturze dziecięcej. Od Grimmów do Gaimana, powołując się na powyższe ustalenia, dokonuje szczegółowej egzegezy grozy w baśniach magicznych, folklorze dziecięcym oraz literaturze dla niedorosłych. Uzupełnianie prowadzonych przez nią badań byłoby zadaniem karkołomnym, choć warto podjąć próbę włączenia w obszar rozpoznany przez badaczkę zagadnień związanych z szeroko dziś dyskutowaną ideą antropocenu, który, jak się wydaje, może generować teksty literackie $\mathrm{z}$ jednej strony spełniające kryteria estetyczne horroru, a z drugiej - dzięki podejmowanej problematyce - otwierające dyskusję nad istotnymi problemami współczesności. Mimo że dość łatwo dziś można wyobrazić sobie horror o tematyce ekologicznej, to czytelnikowi bliższe wydają się jednak tego typu narracje realizowane przez literaturę science fiction, w której temat katastrofy ekologicznej bywa na tyle mocno eksploatowany, że doczekał się już wyodrębnienia swoistej ekotopiki. To jednak nie wszystko. Eric M. Conway, współautor głośnej książki Upadek cywilizacji zachodniej. Spojrzenie z przyszłości (Oreskes, 
Conway, 2014/2017), przekonuje, że dla literatury science fiction zaangażowanej w ekologiczne narracje punktem odniesienia są badania naukowe, więcej - ona sama ma na nie wpływ. Przykładem tego typu relacji jest właśnie wspomniana publikacja, będąca na tyle ważną narracją science fiction, znakomicie udokumentowaną danymi na temat klimatu oraz polityki klimatycznej, że spotkała się z entuzjastycznym przyjęciem naukowców, doceniających jej alarmistyczną rolę (Popkiewicz, Kardaś, Malinowski, 2019). Conway argumentuje, że:

Fantastyka naukowa już od kilku dekad zgłębia kwestię zmiany klimatycznej i zakłóceń klimatu. Pierwszym autorem, o którym wiem, że poważnie przyglądał się relacji ekosystemów i ludzkiej aktywności, był Frank Herbert. Jego wydana w 1965 roku Diuna stanowiła fascynujące studium tego, w jaki sposób ekosystem jednej planety wpłynął na całe imperium galaktyczne. Najbardziej jednak wpłynęły na nas dwie trylogie Kima Stanleya Robinsona - Trylogia Marsjańska oraz Trylogia Zmiany Klimatycznej [...]. Obie te opowieści są skomplikowane, ale podstawowa narracja Trylogii Marsjańskiej dotyczy konfliktu o to, jak zmieniać klimat Marsa, aby możliwe stało się zamieszkiwanie na tej planecie [...]. Trylogia Zmiany Klimatycznej została napisana w sposób realistyczny - niektórzy mogą w ogóle nie uznać jej za fantastykę naukową, gdyż została ona ściśle oparta na ustaleniach naukowych, podobnie jak nasza opowieść (Orseskes, Conway, 2014/2017, s. 125-126).

Włączenie do dyskursu o antropocenie gatunków należących do literatury popularnej wydaje się czymś tak samo naturalnym, jak stosowanie współczesnych metodologii wobec kanonicznych już tekstów. O ile więc eksperyment genologiczny wyrasta z potrzeby poszukiwań nowych narracji, a jednocześnie uwrażliwiania czytelników na zmiany, jakie zaszły i zachodzą w środowisku, o tyle poszukiwania metodologiczne reprezentowane np. przez humanistykę ekologiczną ${ }^{1}$ (Domańska, 2013) czy ekokrytykę mają nie tyle zmienić kanoniczne sposoby interpretacji znanych dzieł, ile w ogóle uczulić na dotychczasowe sposoby ich odczytywania, podporządkowane wyłącznie antropocentrycz-

1 Biorąc pod uwagę rozstrzygnięcie zaproponowane przez Ewę Domańską (2013), w artykule będę posługiwać się przede wszystkim terminem "humanistyka ekologiczna” [ecological humanities], choć jest on często stosowany wymiennie z pojęciem humanistyki środowiskowej [environmental humanities] lub humanistyki zrównoważonej [sustainable humanities]. Domańska przekonuje, że tego rodzaju działanie prowadzi do fałszywej synonimii znoszącej różnice między tymi terminami. Badaczka przypomina, że humanistyka środowiskowa jest związana z ruchami ochrony środowiska, podczas gdy „ekologizm jest pojęciem znacznie szerszym i dotyczy nie tylko specyficznej idei wiedzy/nauki, jej uprawiania i sposobu poznania, lecz także zmiany świadomości" (s. 14). 
nemu oglądowi świata. Pomijając spory badaczy dotyczące wykonalności tego zadania, warto odnotować prawdziwy wysyp książek proponujących nowy tryb lektury².

Tym samym paradoksalny wydaje się fakt, że perspektywa nieatropocentryczna zdominowała badania kultury antropocenu, który jest pojęciem dość nowym, choć, jak twierdzą badacze, opisuje okres od opatentowania silnika parowego przez Jamesa Watta w 1784 roku po współczesność (Bińczyk, 2018, s. 11). Warto przypomnieć, że dopiero w 2000 roku amerykański biolog Eugene F. Stoermer oraz holenderski badacz atmosfery Paul J. Crutzen zaproponowali, aby współczesną epokę geologiczną nazwać antropocenem, co oznacza „epokę człowieka" (Bińczyk, 2018, s. 11). Według zwolenników tego pojęcia aktywność człowieka (m.in. urbanizacja świata, eksploatacja paliw kopalnych, zanieczyszczenie środowiska, emisje gazów cieplarnianych) obecnie jest tak silna, że staje się najpoważniejszym czynnikiem przeobrażającym Ziemię. Nie dziwi więc fakt, że antropocen „coraz bardziej organizuje współczesną wyobraźnię i pobudza do działania” (Bendyk, 2015, s. 28), kreując dwie sprzeczne opowieści: optymistyczną (zatrzymanie zmian na Ziemi jest możliwe, tak jak możliwe jest przekonstruowanie naszej świadomości, koncentrującej się na myśleniu oraz działaniu prośrodowiskowym) oraz pesymistyczną (katastrofa polegająca na zniknięciu natury, zarówno w sensie symbolicznym rozumianym jako wyrugowanie jej ze społecznej wyobraźni, jak i fizycznym, będącym efektem nadmiernej eksploatacji przyrody). Antropocen uruchamia na tyle ważne

\footnotetext{
Warto wymienić choć kilka: Pisarze w zwierzyńcu (Abramowska, 2010), Zwierzęta, gender i kultura. Perspektywa ekologiczna, etyczna i krytyczna (Barcz, Dąbrowska, 2014), Zwierzęta $i$ ich ludzie. Zmierzch antropocentrycznego paradygmatu (Barcz, Łagodzka, 2015), Realizm ekologiczny. Od ekokrytyki do zookrytyki w literaturze (Barcz, 2016), Cyborg w ogrodzie. Wprowadzenie do ekokrytyki (Fiedorczuk, 2015), „Dlaczego gęsi krzyczały?”. Zwierzęta i Zagłada w literaturze polskiej XX i XXI wieku (Krupiński, 2016), Jedna przyroda czy przyrody alternatywne? O pojmowaniu i obrazach przyrody w polskiej poezji (Tabaszewska, 2010), Post-koiné. Studia o nieantropocentrycznych językach (poetyckich) (Jarzyna, 2019). Literatura dla niedorosłych doczekała się również tego typu opracowań, choć pewnie to dopiero początek badań: Czytanie menażerii. Zwierzęta w literaturze dziecięcej, młodzieżowej i fantastycznej (Mik, Pokora, Skowera, 2016), Doktor Dolittle i jego zwierzęta - lektura ekokrytyczna (Mytych-Forajter, 2015), „Tę książkę wymyślit pies”. Ferdynand Wspaniały Ludwika Jerzego Kerna jako lektura ekokrytyczna (Gralewicz-Wolny, 2015), Zwierzęta i ich dzieci - poznanie, empatia, etyka. Perspektywa ekokrytyczna w literaturze dla dzieci i młodzieży (Rąbkowska, 2017). Cieszy fakt, że badacze zdołali dostrzec wagę ekokrytycznych badań nad antropocenem, wskazując przy tym pilną potrzebę ich transmisji do dydaktyki szkolnej. Pierwszą tego rodzaju propozycją jest książka Literatura i jej natury. Przewodnik ekokrytyczny dla nauczycieli i uczniów szkół średnich pod redakcją Przemysława Czaplińskiego, Joanny B. Bednarek oraz Dawida Gostyńskiego (2017).
} 
i spektakularne tematy, że trudno nie zgodzić się z Brunonem Latourem (2014), który podczas wykładu dla Amerykańskiego Towarzystwa Antropologicznego przekonywał, iż idea „epoki człowieka” jest przede wszystkim wspaniałym podarunkiem badaczy nauk ścisłych dla humanistów. Nie powinniśmy jednak zapominać, że próby rozbicia antropologicznego paradygmatu były podejmowane dużo wcześniej przez wewnętrznie niejednorodną posthumanistykę. To, co jednak różnicuje badania nad antropocenem od wcześniejszych koncepcji odchodzenia od idei antropocentryzmu, to paradoksalnie powrót do człowieka, ale na zupełnie innych zasadach. Otóż antropocen generuje jedno, główne pytanie. Mianowicie pyta o zakres ludzkiej sprawczości i odpowiedzialności za kształt współczesnego świata, nie tylko Ziemi, ale w ogóle systemów planetarnych. Tym samym, jak wykazał Latour, „w fundamentalny sposób wpływa to na podniesienie prestiżu nauk humanistycznych, ekofilozofii i etyki środowiskowej, a także prestiżu samej debaty na temat antropocenu" (za: Bińczyk, 2018, s. 28).

Do badania narracji o antropocenie z pewnością przydatne będzie ekokrytyczne instrumentarium zaangażowane w „wyjaśnienie genezy i charakteru ludzkich praktyk decydujących o sytuacji środowiska oraz poszukiwanie sposobów korygowania tej sytuacji” (Czapliński, 2017, s. 182). Tym samym ekokrytyka bierze na siebie odpowiedzialność opisu nie tylko zmian w relacjach między światem ludzkim i pozaludzkim, ale także tworzenia scenariuszy wychodzenia ze środowiskowego kryzysu. Jak pisze Przemysław Czapliński, ekokrytyka czerpie inspiracje $\mathrm{z}$ wielu metodologii (dekonstrukcja, badania kulturowe, badania postkolonialne, feminizm), a preferowana przez nią analiza dzieła literackiego uwzględnia następujące pytania:

[... 1) jak w badanym tekście przedstawia się różnica kultura-natura i jakie pociąga za sobą konsekwencje w obrębie świata przedstawionego? 2) z jakich tradycji (religijnych, filozoficznych, politycznych, naukowych) podział się wywodzi? 3) jakie praktyki materialne w świecie pozatekstowym dane dzieło wspiera? 4) jak można zmienić wynikające $z$ tekstu wyobrażenia o naturze i odpowiadające temu praktyki? (s. 183).

To, co wydaje się szczególne istotne w ekokrytycznym oglądzie i zarazem w humanistyce ekologicznej, skoro ta ostatnia ma wypracować plan przeciwdziałania zmianom wywoływanym przez człowieka, to oczywiście nacisk położony na wychowanie, przygotowujące kolejne pokolenie do tego, aby nie tylko umiało funkcjonować w nowym, odmiennym od naszego świecie, ale przede wszystkim było zdolne do pokonywania ograniczeń uniemożliwiających ratowanie środowiska. Jeżeli kryzys ekologiczny jest zarazem kryzysem ludzkiej 
cywilizacji, konieczne wydaje się wypracowanie nowej formuły kultury. Z poszukiwań takiego „wzorca” rodzi się koncepcja kultury ekologicznej, której główne przesłania można sprowadzić do czterech podstawowych cech. Ma być to kultura: „przyjazna Ziemi i przyrodzie; bazująca na wizji prometejskiej, a nie faustycznej; duchowa w sensie kosmicznym; partycypująca w sensie głębokiego zrozumienia, że w czym partycypuję, tym się staję" (Skolimowski, 2003, s. 197). Powyższe wyznaczniki z pewnością mogą stać się punktami orientacyjnymi dla osób odpowiedzialnych za edukację oraz podstawy programowe ${ }^{3}$, choć jak się zdaje, to właśnie literatura, a nie szkoła, szybciej i chętniej reaguje na humanistyczny apel o konieczne zmiany w zakresie myślenia o środowisku. Miażdżącą diagnozę edukacji w tym zakresie przynosi klasyczna już dziś książka Umyst i przyroda. Jedność konieczna Gregory'ego Batesona (1979/1996), w której znany antropolog przekonuje:

Dlaczego szkoły prawie niczego nie uczą o wzorcu, który łączy? Czyżby nauczyciele wiedzieli, że niosą pocałunek śmierci, który obróci w nijakość wszystko, czego dotkną, i dlatego mądrze nie chcą tykać ani nauczać niczego, co jest naprawdę ważne $\mathrm{w}$ życiu? [...] Jakiż to wzorzec łączy kraba $\mathrm{z}$ homarem i storczyk z pierwiosnkiem, a całą tę czwórkę z nami? A ciebie ze mną? I wszystkich nas sześcioro $\mathrm{z}$ amebą $\mathrm{z}$ jednej strony, a $\mathrm{z}$ zamkniętym $\mathrm{w}$ sobie schizofrenikiem z drugiej? [...] Jak zbudowana jest ta całość? (s. 19).

O ile na wypracowanie edukacyjnej refleksji o wszystkim jako całości z pewnością trzeba jeszcze będzie poczekać, o tyle literatura dla niedorosłych podejmuje w tym kierunku dość widoczne działania. Szczególnie ostatnio na półkach księgarskich można znaleźć wiele tytułów odpowiadających na alarmistyczne doniesienia zarówno ekologów, jak i humanistów ${ }^{4}$. Tego typu ekoliteratura najczęściej sprowadza się do atrakcyjnie wydanych przewodników oraz poradników, a rzadziej - fabularyzowanych opowieści. W zasadzie większość tytułów ma charakter edukacyjny, a celem autorów jest po prostu opisanie konkretnego zjawiska (np. ginących gatunków fauny i flory, zanieczyszczenia środowiska), postulowanie rozwiązań problemów ekologicznych oraz propagowanie wśród najmłodszych zachowań proekologicznych. Wśród tego

3 Obliczono, że wśród ponad 2000 tematów w podstawie programowej realizowanych w szkole podstawowej nie ma takich terminów jak: „zmiana klimatu”, „emisja CO2”, „topnienie lodowców”, „efekt cieplarniany” (Pacewicz, 2019).

4 Warto przyjrzeć się najnowszej ofercie książek dla najmłodszych na temat ekologii, np. przeglądając kategorię Ekologia dla dzieci na stronie księgarni internetowej Ambelucja (https://www.ambelucja.pl/). 
typu tekstów, nazwijmy je, prewencyjnych, rzadko zdarza się książka, która po pierwsze realizowałaby Batesonowski postulat wzorca, wyrażający się w podkreślaniu relacji między tym, co ludzkie, a tym, co nie-ludzkie, a po drugie wpisywałaby to „przesłanie” $\mathrm{w}$ rozpoznawalny gatunek literacki ${ }^{5}$.

Czy w literaturze dla dzieci i młodzieży jest więc miejsce na horrory pisane w duchu antropocenu i humanistyki ekologicznej, poddające się choć częściowo ekokrytycznemu opisowi?

Przyznaję, że znam tylko jedną taką propozycję, choć proponowane przez ekokrytykę modele lektury umożliwiają dostrzeżenie w niejednym utworze takich treści, o których nie śniło się czytelnikom sprzed antropocenu. Zresztą w ekokrytycznej lekturze chodzi przecież o czytanie raz jeszcze, wyostrzające uważność, umożliwiające układanie opowieści według nowych wzorców ${ }^{6}$, choć te nie powinny być tworzone $\mathrm{w}$ ramach radykalnych założeń metodologicznych. Peter Barry (2002/2017), przeciwstawiając się fundamentalizmowi wszystkich przedrostków i przyrostków uzurpujących sobie prawo do takiej, a nie innej szkoły czytania, twierdzi, że:

Nie istnieje [...] żaden konkretny, powszechnie uznany model ekokrytycznego postępowania, którego moglibyśmy się nauczyć i który następnie moglibyśmy zastosować. Często jest to jedynie kwestia podejścia do - być może - dobrze znanego dzieła $\mathrm{z}$ większym wyczuleniem na omówione kwestie; od zawsze unosiły się one nad danym tekstem, my jednak nigdy wcześniej nie poświęciliśmy im pełni uwagi (s. 30).

5 Warto w tym miejscu zaznaczyć, że być może wyjątkiem od tej zasady jest seria kryminałów dietetycznych dla dzieci Walenty i spółka Moniki Oworuszko (2015-2019). Autorka, propagując zdrowy styl życia, odwołuje się do rozpoznawalnego gatunku literackiego, co z kolei ośmiela do sformułowania twierdzenia, że promowaniu zachowań proekologicznych wśród dzieci sprzyjają nie tylko teksty popularnonaukowe, ale i beletrystka gatunkowa.

6 Znakomicie o zjawisku kolejnej lektury tego samego tekstu pisze w We Talk About When We Talk About Ecocriticism Ralph W. Black (1994): „Nie tak dawno temu widziałem znów Króla Leara z Laurence'em Olivierem w roli głównej. Jak zwykle podziwiałem głęboki gniew i jeszcze głębszy smutek tytułowego bohatera i jak zwykle popłakałem się na końcu, gdy niósł on przez całą scenę ciało Kordelii. Ale bardziej uderzył mnie początek: mapa królestwa leży rozwinięta, namalowana na wyprawionych skórach małego stada królewskich jeleni. Stary Władca używa miecza, by symbolicznie podzielić swoje królestwo pomiędzy córki. Jeszcze nim córki słowem, czy też jego brakiem, zaświadczą o sile swojej miłości, dochodzi do skandalu: utowarowiony krajobraz zostaje pokrojony i wydany tej, która da najlepszy popis retoryki. Przez moment zacząłem zastanawiać się nad tym, jak rozumem tę tragedię. Zwróciłem uwagę na aroganckość czynu prowadzącego Leara do upadku, na znaczenia, jakie w sztuce mają świat przyrody i chwile jasności - każda z nich zdaje się wydarzać gdzieś na zewnątrz w trakcie burzy, na wrzosowisku, na brzegu morza" (za: Barry, 2002/2017, s. 30). 
Korzystając z powyższej rady, jesteśmy w stanie $\mathrm{z}$ wielu tytułów adresowanych do niedorosłych czytelników wyczytać treści w duchu humanistyki ekologicznej, nie podejrzewawszy wcześniej znanych utworów o tego rodzaju przesłanie. Autorzy książki, o której zamierzam napisać, w pewnym stopniu ułatwili odbiorcy zadanie, wpisując ją w genologiczne ramy, w jakimś sensie ukierunkowując lekturę. Daniel Chmielewski i Magda Rucińska, twórcy Miasta Złotej (2018), nazwali swój tekst horrorem urbanistycznym. Na okładce można przeczytać wyjaśnienie takiej decyzji:

Autor Burz kuchennych i bestii bezsennych [...] oraz malarka [...] przedstawiają horror urbanistyczny dla najmłodszych! Tylko nieokiełznana wyobraźnia, myślenie poza schematami i praca zespołowa pozwolą bohaterom oraz czytelnikom zrozumieć i okiełznać ten nieobliczalny, groźny i jedynie z pozoru uporządkowany świat (czwarta strona okładki).

Zaryzykuję twierdzenie, że o ile nie warto spierać się o ustalenia autorów dotyczące gatunku, o tyle można podyskutować o rozszerzeniu kategorii urbanistyki o kategorię ekologii. Dlatego też Miasto Złotej, książka napisana w okresie szczególnego zainteresowania ekologią i ekokrytyką, mogłaby z powodzeniem funkcjonować w czytelniczym (szkolnym) obiegu jako tekst bliski ideom humanistyki ekologicznej.

Kilka słów o fabule. Główną bohaterką opowieści jest Złota, samotna dziewczynka mieszkająca w wielkim, betonowym mieście. Pozbawiona opieki rodziców, polega jedynie na przyjaciołach: Misiu i lalce Tinie, ożywionych zabawkach. Miasto bez nazwy jest dosłownie betonową dżunglą: wydaje się nieskończone i nikt w nim nie mieszka. O dziwo, nie przeraża to Złotej, wręcz przeciwnie - nauczyła się czytać przestrzeń, której budulec, choć wydaje się jednolity, tak naprawdę może być zaskakująco zmienny. Beton, w zależności od pory dnia, roku czy materiałów go tworzących, może przyjmować różne barwy, zmieniać swą temperaturę, a nierzadko i fakturę. Złota wraz z przyjaciółmi spaceruje po labiryncie ulic, wchodzi do pustych sklepów, bawi się w sprzedawcę i kupującego, jednym słowem - betonowe miasto staje się tłem jej dzieciństwa. Ulubione zajęcie gromadki to rysowanie, a niedokończonym dziełem jest mapa, która w zasadzie jako jedyny niebetonowy artefakt wprowadza do świata Złotej jakieś kolory. Rzecz w tym, że miejski krajobraz nie daje się łatwo przenieść na mapę, wszak mapa i terytorium to nie to samo. Gąszcz budynków, a co gorsza nieustanne zmiany zachodzące w tkance betonowej architektury, uniemożliwiają bohaterom ukończenie mapy. Ulice zmieniają swe trajektorie, a niektóre przestają istnieć, tylko po to, aby w nieoczywistych miejscach powstały inne; u wylotu ulic, na placach wyrastają nagle przed 
bohaterami wysokie ściany, odgradzając ich od tego, co dotąd było im dobrze znane. Przestrzeń z jednej strony przypomina pleniące się, wręcz drapieżnie rozrastające się nowoczesne miasta, których apetyt każe pochłaniać wszystko, co napotka na swej drodze, niszcząc istniejącą już zabudowę. Rozprzestrzenianie się, zarówno wertykalnie, jak i horyzontalnie, powoduje efekt nie tylko zacienienia miejskiej przestrzeni, ale i chłodu oraz nigdy nieustającego wiatru (przykład Nowego Jorku i tzw. praw powietrznych). Warto w tym miejscu przypomnieć etyczne wezwanie z Siedmiu lamp architektury Johna Ruskina (1849), który przekonywał:

[...] nie jest sprawą doraźnego celu, czy powinniśmy chronić budynki z przeszłości, czy nie. Nie mamy prawa ich dotykać. One do nas już nie należą. Należą częściowo do tych, którzy je budowli, a częściowo do wszystkich pokoleń, które po nas przyjdą (za: Scruton, 2012/2017, s. 322).

Ilustracje Rucińskiej skutecznie wspierają wrażenie drapieżności oraz wrogości przestrzeni. Oryginalny format książki, dość niewygodny podczas lektury, powoduje, że dyskomfort przestrzeni betonowego miasta jest niemal odczuwany przez czytelnika. Ilustracje są duże, ale ubogie w szczegóły. Graficzka rezygnuje z drobiazgowych przedstawień na rzecz pewnego rodzaju rutyny: postaci poruszają się w podobnym otoczeniu, którego kolorystyka utrzymana jest w zimnych bielach, błękitach, szarościach oraz granatach. Ciepłe barwy są reprezentowane przez pomarańczowe włosy Złotej oraz pojawiające się rysunki wykonanych przez bohaterów map. Umieszczono na nich sześciany i prostopadłościany. Geometryczne bryły tylko pozornie nawiązują do estetyki miasta Złotej. Choć przypominają drewniane klocki, korespondujące z żywiołem zabawy, w której często uczestniczą postacie, to stanowią także czytelne odwołanie do samego aktu projektowania miasta, w przypadku metropolii Złotej wydającego się nie mieć zasad. Klocki wprowadzałyby wszak jakąś regularność oraz ład, tymczasem bezkształty beton zalewający przestrzeń niweczy tego rodzaju plany. Wszystkie rysunki wykonane przez postaci - mapy, plany, rzuty pionowe i poziome klocków, przerywane kolorowe linie - wprowadzają do beztroskiej zabawy nową jakość. Złotowłosa chce zmian, przemodelowania miasta, choć sama nie wie, skąd bierze się ta potrzeba oraz jaki kształt powinna przyjąć.

$\mathrm{Z}$ drugiej strony, ta sama przestrzeń przypomina postapokaliptyczne miasto, którego architektura sprowadza się do plątaniny kryjówek, bunkrów oraz labiryntów, będących zarówno zagrożeniem dla człowieka, jak i ratunkiem. Miasto Złotej to pewnego rodzaju Metropolis, w którym „jednostka wydaje się zerem”, $\mathrm{z}$ tą różnicą, że w mieście nie widać zarządzających tą przestrzenią, co jednak nie znaczy, że władzę nad nią ma Złotowłosa. Jest jeszcze gorzej: betonowa masa 
wydaje się przerażającym superorganizmem, samowystarczalnym, samoregulującym się i jednocześnie niszczycielskim, pożera bowiem wszystko, co napotka na swej drodze. Beton jest wsobny, a jego skupienie wyłącznie na sobie skutkuje nie tylko zmarginalizowaniem, ale i anihilacją każdej formy życia.

W takim kontekście ilustracje Rucińskiej zyskują nową jakość, wszak monochromatyczność nie będzie oznaczać monotonii betonu, nudy przestrzeni, która prowokuje Złotowłosą do jej przekonstruowania. Grafika ukazująca postaci niby w świetle jarzeniówki wydobywa z nich niepokojącą trupiość. Ale to nie wszystko. Dziewczynka wśród swych przyjaciół, Misia i lalki, jako jedyna jest „żywa”, choć zabawki oraz jej postać wykreowane przez Rucińską przypominają zombie. Trupia bladość twarzy, podkrążone czarną, grubą kreską oczy, czarne usta, ostre kontrasty, sylwetka szmacianej lalki oraz czarno-biały strój, czyniący z sylwetki postać z balu wampirów, sprawiają wrażenie niesamowitości. Dodatkowo postacie poruszają się w przestrzeni wypełnionej cieniami budynków, chmur czy też własnych sylwetek. I choć puste place nieco przypominają metafizyczne malarstwo Giorgia de Chirico, to jednak pozbawione są tak charakterystycznego dla jego obrazów ciepła barw oraz dojmującej nostalgii. U Chmielewskiego i Rucińskiej kraina cienia jest miejscem wygnania, które wbrew deklaracjom Złotej, twierdzącej, że miasto może się podobać, nie jest przestrzenią przyjazną żywym ${ }^{7}$.

Oczywiście taka kreacja przestrzeni może uzasadniać adres genologiczny wskazany przez autorów: horror urbanistyczny, wywołujący do tablicy problem estetycznego zagospodarowania przestrzeni, uwzględniającego potrzeby jej mieszkańców. O tym, że Polacy mają z tym problem, mogliśmy się przekonać po publikacjach Piotra Sarzyńskiego czy Filipa Springera, a ostatnio dzięki „edukacyjnej” aktywności tandemu Radosław Gajda i Natalia Szcześniak - autorów bloga Architecture is a GOOD IDEA (2015-2018) oraz niedawno wydanej książki Archistorie. Jak odkrywać przestrzeń miast? (2018). Jeszcze kilka lat temu, niezainteresowana zupełnie humanistyką ekologiczną, z pewnością przystałabym na taką propozycję odczytania tekstu, a także próbowałabym forsować inne interpretacje. W opowieści o złotowłosej ${ }^{8}$ dziewczynce

O Wieku Półcienia piszą w bazującej na wiedzy naukowej, ale beletrystycznej książce Upadek cywilizacji zachodniej wspomniany wcześniej Eric M. Conway i Naomi Oreskes (2014/2017). Termin oznacza prowadzący do katastrofy okres antyintelektualizmu, który uniemożliwił podjęcie działań opartych na dostępnej w XXI wieku wiedzy naukowej. Należy odnotować, że w 2020 roku w Muzeum Sztuki Nowoczesnej w Warszawie będzie można oglądać wystawę pod tytułem Wiek Półcienia, nawiązującą do tej opowieści science fiction.

8 Być może kolor włosów bohaterki nie jest bez znaczenia. W literaturze „ekologicznej” często Słońce nazywa się Złotowłosą: „Ziemia jest planetą Złotowłosej, położoną nie na tyle 
widziałabym popularne wtedy tropy, np. samotność dziecka, opresyjność otoczenia, oniryczną narrację czy przypowieść o dziecięcym cierpieniu, którego źródłem są patologiczne zachowania dorosłych. Wtedy zagrażające mu betonowe miasto byłoby metaforą zła, podobną funkcję pełni przecież architektura w Domu nie z tej ziemi Małgorzaty Strękowskiej-Zaremby (2017).

Opowieść o Złotej można jednak czytać jako sprzeciw wobec niekontrolowanej rozbudowy tkanki miejskiej, zalewania betonem miejsc, które wcześniej służyły rekreacji oraz spotkaniom i w ogóle jako bunt przeciwko utowarowieniu przestrzeni. Jeśli weźmiemy pod uwagę wcześniejsze projekty autorów książki, ich zainteresowanie estetyką (oboje skończyli szkoły artystyczne: Chmielewski Akademię Sztuk Pięknych w Warszawie, a Rucińska - w Poznaniu), nietrudno zgodzić się na taką interpretację. Według mnie horror wykreowanej przestrzeni zasadza się na fundamentalnej zasadzie, sformułowanej przez norweskiego architekta Christiana Norberga-Schultza (1971): „[...] skala krajobrazu stanowi podstawę, na której ujawniają się konfiguracje przestrzeni egzystencjalnej" (za: Kopczyński, 2008 s. 92). Innymi słowy, krajobraz tworzy nie tylko życiową przestrzeń, ale również scenografię dla ludzkich przygód, a jakby tego było mało, wpływającą na ich kształt. Przyjmując sugestie twórców Miasta Złotej, należy się również zgodzić z Has-Tokarz (2006), która przekonuje, że:

Przestrzeń $\mathrm{w}$ horrorze w równym stopniu jest, co znaczy [...]. Bez względu na to, jaki kształt formalny przybiera miejsce, w którym rozgrywają się zdarzenia i umieszczony jest bohater, zawsze jest to „[...] obszar groźny, narażający protagonistów na różne przeprawy i generujący liczne niebezpieczeństwa” (s. 485).

Rzeczywiście, przestrzeń w Mieście Złotej nie jest mapowana elementami znanymi z horrorów. Na próżno w opowieści szukać „przestrzennej” topiki grozy w tradycyjnym ujęciu, o którym pisze Slany (2016), sprowadzając ją do dwóch przydatnych pojęć: exterior oraz interior (s. 27, 258). Czytelnik ma wrażenie, że bohaterowie znaleźli się $\mathrm{w}$ przestrzeni à rebours, a znane mu dotąd zasady fabularne związane $\mathrm{z}$ topografią grozy w tym przypadku nie działają. W mieście Złotej przede wszystkim brakuje centrum, a dom, na który zresztą dziewczynka się nie uskarża, nie tyle zmienia swe położenie, ile znajduje się w sytuacji niepewnej, gdyż krajobraz go otaczający podlega ciągłym transformacjom. Są one powodem niestabilności przestrzeni, którą bohaterowie, wykonując mapy, próbują gestem artysty architekta przywrócić do porządku. Ich

blisko swej gwiazdy, by spiec się na skwarek, i nie na tyle daleko, by skuł ją wieczny lód" (Wilson, 2016/2017, s. 187). 
działania okazują się bezskuteczne, wszak mapa nie oddaje zmian zachodzących w obrębie terytorium, które odwzorowuje. Zmiany betonowej przestrzeni są szybkie, drapieżne i zastępują nie tylko rytm pór roku (widok z okna Złotej umożliwia jedynie obserwacje przekształcania się betonowych form, a nie cyklu natury). W ruchu betonu można również widzieć niejako „zastępczą" i tym samym pseudogenealogiczną opowieść o historii Ziemi, z tą różnicą, że miasto Złotej nie jest podporządkowane siłom natury, ale zupełnie niezdefiniowanym mocom, dokonującym nieustannych oraz niezrozumiałych transformacji przestrzeni. Beton się wypiętrza, zapada, zalewa, rośnie, wnika, pokrywa; jest aktywny, dominujący, ale co ważniejsze - wsobny i samoistny. Najlepiej charakteryzuje go zaimek „się". Ta cecha betonu sprawia, że choć w opowieści wspominane są drewniane domki na obrzeżach miasta i kamienice z cegły, to tak naprawdę należą już one do legendy, a pochłonięte przez beton niszczący niczym lawa wszystko na swej drodze, nie tworzą już przestrzeni, którą można by nazwać obrzeżami czy peryferiami (Slany, 2016, s. 27). W horrorze urbanistycznym brakuje więc centrum i obrzeży, a co za tym idzie - nie ma również istot je zamieszkujących: poczwar, demonów czy upiorów (Eliade, 1957/1999, s. 68). Tym samym egzotyczna dla narracji będzie przestrzeń exterior, którą w baśniach magicznych, jak przekonuje Slany (2016) za Brunonem Bettelheimem i Władimirem Proppem, tworzy las: „miejsce przynależne $\mathrm{w}$ tradycji wierzeniowej obłąkanym, obcym, czarownicom, mordercom. Banitom, demonom, wilkom, czyli wszelkim istotom o destrukcyjnej tożsamości, wzbudzającej paniczny strach" (s. 27-28). Nie ma ona swej opozycji. Przestrzeń interior, rozumiana jako miejsce powszechnego bytowania, $\mathrm{z}$ niezmienną wewnętrzną organizacją, oraz zorientowana wobec stałych elementów (centrum i peryferii), po prostu nie istnieje. Zarówno dom, jak i przestrzeń poza nim budzą grozę. I odwrotnie: tak dom, jak przestrzeń poza nim grozy nie budzą, ponieważ jej mieszkańcy nie znają innych miejsc, a tym samym nie biorą pod uwagę innych życiowych scenariuszy: „Powiem, czego nie ma w mieście Złotej. Nie ma roślin. Nie ma drzew ani trawy, ani owoców. Może dlatego Złotej tak się podoba jej miasto - bo nie wie, że mogłoby wyglądać inaczej” (Chmielewski, 2018, s. [8]). W tym miejscu horror urbanistyczny przekształca się w horror ekologiczny (Has-Tokarz, 2015, s. 88) ${ }^{9}$, zasadzający się na kryzysie epistemologicznym wyrażającym się w niemożności ujrzenia różnicy.

9 Choć używam terminu „horror ekologiczny” i przywołuję pracę Has-Tokarz, to jednak nieco inaczej w kontekście lektury Miasta Złotej rozumiem jego znaczenie. O ile dla badaczki natural horror, ecological horror oraz animal attack horror realizują motyw krwiożerczej natury, która odgrywa się na człowieku za spustoszenie, jakie jest skutkiem jego działań, 
Złota nie wie, że można żyć „inaczej”. Nie zna przecież wzorca, mogącego stać się probierzem rzeczywistości, w której jest zanurzona. Płynność betonu nieustannie zmienia przestrzeń, nie dopuszczając, aby powstały w niej jakieś punkty orientacyjne. Wyklucza to więc porównywanie. Wspomniany wcześniej Bateson, upominający się o wzorzec, przekonuje, że jest on o tyle potrzebny, o ile sprzyja temu, aby „postrzeżenie różnicy uruchamia[ło] [...] proces poznawczy [...]. Rozpoznawanie różnicy zmusza poznającego do selekcji postrzeżeń i wyboru jedynie znaczących" (za: Wyka, 1996, s. 310). Brak kategorii różnicy nie pozwala na wyodrębnienie, oddzielenie i wyróżnienie, jednym słowem, wyklucza wiedzę, że można „inaczej”. Odkrycie różnicy to prawdziwy wstrząs, co raczej nie dziwi, jeśli przypomnimy sobie słowa Platona o wychowaniu, którego istotę stanowi zwrócenie duszy w kierunku źródła światła, czy to, co przytrafiło się Szawłowi w drodze do Damaszku. Spotkanie z ,inaczej” poraża, ścina z nóg, olśniewa, daje do myślenia, zmienia perspektywę (Maliszewski, 2015, s. 111).

W przypadku Złotej jest nim poznanie Sylvy, niemal jej sobowtóra, dziewczynki różniącej się od Złotej tylko jedną cechą: kolorem włosów, które u Sylvy są srebrne. Spotkanie poprzedza bolesny incydent - zranienie się przez Złotą drzazgą pochodzącą z nieznanego jej świata, sprzed ery betonu. Rana, choć niewielka i niebolesna, daje do myślenia. Drzazga nieprzypominająca niczego, do czego dziewczynka byłaby przyzwyczajona, tworzy precedens. W tym sensie kawałek drewna w świecie zalanym betonem ma status „niesamowitego” - w znaczeniu, jakie temu określeniu nadał Zygmunt Freud (1919/1997) - podobnie jak spotkanie z sobowtórem (s. 236). Na początku wydaje się przerażający, gdyż przypomina o istnieniu różnic i granic, podających w wątpliwość

o tyle omawiany tekst zamiast natury wprowadza element krwiożerczej kultury/cywilizacji pożerającej swe dzieci. Świat natury jest „wyzerowany”, a agon to starcie człowiek versus cywilizacja, swoisty potwór Frankensteina, którego stworzyła ludzkość. Wydaje się, że również popularny ostatnio termin urban fantasy nie do końca przystaje do Miasta Złotej. Na próżno w opowieści o betonowym mieście szukać najważniejszych wyznaczników tego podgatunku opisanego m.in. przez Stefana Ekmana (2016/2018). Według badacza dla identyfikacji urban fantasy jako podgatunku istotne jest nadanie odpowiedniej funkcji miejskiej przestrzeni zamieszkiwanej przez ludzkich i paraludzkich bohaterów najczęściej pozostających w konflikcie. Metropolitalna przestrzeń, a w zasadzie powstające w niej tunele, przekopy, krótko mówiąc, fałdy, służą protagonistom za schronienie. Tymczasem w Mieście Złotej metropolia jest nie tylko ważnym dla tego podgatunku tłem, ale czymś więcej - głównym antagonistą zagrażającym dzieciom. Z uwagi na to, być może adekwatniejszym terminem określającym książkę Chmielewskiego i Rucińskiej byłoby pojęcie urban horror, łączące niejako zarówno wspomniane badania Has-Tokarz, jak i literaturę poświęconą fantastyce miejskiej. 
homogeniczną, bo betonową, przestrzeń miasta. Zranienie drzazgą oraz pojawienie się dziewczynki o srebrnych włosach przypomina, że:

[...] podstawowy podział świata przedstawionego i jego elementów w utworach grozy przebiega zwykle wzdłuż linii „swoje”/,obce”, „my”/,oni” [...]. „Swoje” $i$ „nasze” jest „wspólne”, znane, bezpieczne, akceptowane. Po drugiej stronie stoi „obce”: niebezpieczne, groźne [...]. Granica między „naszym” a „obcym” jest zarazem granicą pomiędzy Dobrem a Złem (Gemra, 2006, s. 501-502).

Skoro ustaliliśmy, że miasto Złotej należy do przestrzeni exterior, pozbawionej odpowiadającej jej, ale zarazem przeciwstawnej przestrzeni interior, to również Sylva, choć „nie stąd”, nie będzie w odniesieniu do Złotej charakteryzowana jako obca. Złota $\mathrm{w}$ relacji z przybyszem dostrzega wszak szansę na wyjście z samotności. Opowieści Sylvy o nieistniejących już przedmieściach, z których sama pochodzi, wprawiają Złotą w konsternację. Zaczyna czuć brak tego, czego nigdy nie poznała, a Sylva, przywracając Złotej utraconą relację z naturą, przestrzenią dotąd jej zupełnie obcą, wyposaża przyjaciółkę w empatię protetyczną ${ }^{10}$ :

Sylva jest podekscytowana, a Złota nie może uwierzyć, że tyle ją ominęło. Jej miasto już nie wydaje się takie ciekawe jak kiedyś. I już nie jest obrażona na drewniany budynek, który ukłuł ją drzazgą. Dziewczynki przez cały czas rozmawiają i okazuje się, że bardzo im ze sobą dobrze. Złota przestała czuć nieufność do nowo przybyłej dziewczynki, a Sylva nie czuje się już samotnie, odcięta od lasu i zwierząt. Co nie zmienia faktu, że obie dziewczynki są zjedzone przez miasto [...] (Chmielewski, 2018, s. [56]).

Sylva, wykorzystując zasadę wzorca i różnicy, odtwarza utracony świat. Okazją do tego rodzaju działań jest industrialna przestrzeń, w której szczelinach, a może Heideggerowskich „prześwitach”, objawia się inna rzeczywistość. Jej odkrycie poraża i wytrąca z równowagi, choć ono samo, mimo swej doniosłości, ma raczej skromny charakter. Takie jest pęknięcie na szybie, które dzięki „różnicy”, pozwalającej na nie inaczej spojrzeć, może być prawdziwą iluminacją:

- Pokażę ci coś - mówi i kuca przy cieniu rzucanym przez pęknięcie w szybie. Wokół niego rysuje poszarpane kształty, których Złota nigdy w życiu nie widziała $[. .$.$] .$

10 Termin nawiązuje do koncepcji pamięci protetycznej sformułowanej przez Alison Landsberg $(2004 / 2012)$. 
- Drzewo! Tak wygląda drzewo! - woła Sylva. - To są liście - wskazuje na poszarpane kształty - to jest pień [...].

- A tak wyglądają kwiaty!

- I ślimak! I motyl!

Sylva dostaje od Złotej wszystkie kredki i rysuje na ścianach i podłodze kolejne rzeczy, które pamięta, a o których Złota nigdy nie słyszała (Chmielewski, 2018, s. [52]).

Rysunek pokrywa betonowe ściany pokoju Złotej. Fresk stworzony przez dziewczynki różni się od innego artefaktu powstającego wcześniej w mieście. Przypomnijmy, że Złota wraz z Misiem i lalką Tiną próbują narysować mapę. Ich wysiłek nie zostaje nagrodzony, bo niestabilność przestrzeni udaremnia zamiary małych kartografów. Inaczej jest z rysunkiem fauny i flory, który wydaje się dziełem skończonym i wręcz doskonałym. Może dlatego, że po pierwsze, to wyraz przedefiniowania idei projektowania nierespektującego dotąd relacyjności istot żywych ${ }^{11}$; po drugie - jest niejako owocem „inicjatywy” oddolnej, bo lokalnej, mikro i dziecięcej, mającej na celu próbę odpamiętania utraconego świata; po trzecie - przywraca myślenie totemiczne, w które wpisuje się poczucie równoległości organizacji świata ludzkiego oraz świata zwierząt i roślin (Bateson, 1979/1996, s. 32). Rysowanie oraz przywoływanie świata „z pamięci” oznacza jednocześnie egzorcyzmowanie przestrzeni exterior, wprowadzanie do niej nowej jakości. Betonowe mieszkanie to współczesna jaskinia Lascaux, $\mathrm{z}$ odbywającym się w niej rytem (warto zwrócić uwagę, że pojęcie to oznacza zarówno obrzęd, jak i rysunek wykonany rylcem) odpamiętywania utraconych relacji z naturą, a także przebłagania Gai za to, co uczynił jej człowiek. Czy autorzy książki, przypomnijmy - artyści - chcą przez to powiedzieć, że to właśnie sztuka jest formą egzorcyzmowania urbanistyczno-ekologicznych lęków oraz ponownego nawiązywania relacji z przyrodą? Dlaczego nie. $\mathrm{W}$ terapeutycznym akcie tworzenia malowidła można również widzieć szansę na pokonanie samotności, ponieważ to właśnie obecność natury „pozwala porządkować stosunki z otoczeniem - ujrzeć je w nowym świetle, odnaleźć sens społecznego współistnienia, zrozumieć znaczenie przyjaźni i miłości oraz szukać dróg więzi wspólnotowych" (Dubas, 2006, s. 336).

Humanistyka ekologiczna nie zadowala się lekturą rozpoznającą nietrudne do zdefiniowania toposy. Ekokrytyka również zachęcałaby raczej do

11 Warto przypomnieć o koncepcji ekologicznego planowania przestrzeni, idei zaproponowanej przez Paula Soleriego, nazywanej arcology (połączenie pojęcia architektury i ekologii), która polega na konstruowaniu zwartej architektury tak, aby pozostałe miejsce oddać naturze (Czochralska, 2001). 
pogłębionych eksploracji tekstu, angażując wyobraźnię czytelnika w tworzenie scenariuszy pozwalających na konkretne działania zmierzające do naprawy świata. Opuśćmy więc jaskinię, ale nie sami, tylko we wspólnocie. Śmiało można tak nazwać grupę bohaterów utworu Chmielewskiego i Rucińskiej: Złotą, Sylvę, Misia i lalkę Tinę. Nie bez kozery tworzą ją dzieci i ich zabawki, przecież w marszach na rzecz klimatu uczestniczą przede wszystkim młodzi. Wydaje się, że Złota i jej przyjaciele, rozumiejąc doniosłość chwili, będącej prawdziwą cezurą antropocenu, zaczynają działać. Rozpoczynają od ustaleń, wszak nowy ład wymaga nowej umowy, a potem przystępują do wykonywania konkretnych zadań. I choć przeciwstawiają się molochowi, to robią to wspólnie oraz według ustalonego planu: zdobywają ziemię i nanoszą ją w wyznaczone miejsca, hodują rośliny, drążą tunele łączące dachy i tarasy, na których zakładają ogródki. Strach zostaje zastąpiony aktywnością, a samotność - wspólnotą.

Jeśli celem horroru jest zawłaszczenie bohaterów i uczynienie ich zakładnikami często własnych lęków, to celem horroru urbanistycznego dla niedorosłych czytelników - uwrażliwienie ich na opresyjność przestrzeni i często nieetyczną, nastawioną na zysk politykę planowania przestrzeni (choć edukacyjny wymiar opowieści z dreszczykiem pozbawiony jest tej „poważnej” terminologii). A co z horrorem ekologicznym, takim jak Miasto Złotej? Nie trzeba chyba nikogo przekonywać, że miasto w tej opowieści jest metaforą Ziemi, a „urbanistyce” odpowiada zniszczenie ziemskich ekosystemów. W tym sensie horror ekologiczny fundowany jest na katastroficznej wizji środowiska, której apokaliptyczna wymowa może jedynie paraliżować. „Ekologiczna” literatura mroku dla dzieci, zgodnie zresztą z postulatami ekokrytyki, dopominającej się o sposoby rozwiązywania problemów, proponuje jednak wyjście z tego impasu, zupełnie podobne do planu działania przedstawionego przez Christiana Schwägerla (Bińczyk, 2018, s. 139). Ten niemiecki dziennikarz odrzuca strach, który proponuje zastąpić racjonalnością i odpowiedzialnością, będącymi podstawą „dobrego antropocenu”, rozumianego jako budowanie zrównoważonej i sprawiedliwej przyszłości. Dzieci z Miasta Złotej realizują ten postulat, ufając sile wspólnotowego działania. Być może to echa lekcji rysunku wykonywanego na betonowych ścianach, lekcji przybliżającej relacje między roślinami, których obserwacja może wiele nauczyć o tym, jak działa wspólnota:

Nie widziałam nigdy pojedynczej łodygi mchu, co zauważać mam zwyczaj u drzew czy różnych roślin. Mszaki zawsze są blisko siebie. I tu tkwi opowieść o ich sposobie na suchą przestrzeń, na własne niedoskonałe, delikatne ciało nieprężące się sztywnymi badylami, a wysycające się tylko czasem wilgocią 
z powietrza [...]. Mchy, rośliny pierwotne, wspierające się, nawadniające się i wrażliwe na środowisko. Ale tylko razem (Zajączkowska, 2019, s. 78, 90).

Jeśli dobry antropocen przywróci myślenie totemiczne, w którego kręgu znajdą się również i mchy, to może właśnie ich obraz zachęci do przeformułowania idei wychowania, przygotowującego nie do świata zastanego i nie do świata, jakim będzie, lecz do działania w świecie zastanym na rzecz świata, jaki powinien być (Muszyński, 1977, s. 37). Przypomnimy sobie o tym, czytając horror ekologiczny zachęcający do troski o świat.

\section{Bibliografia}

Abramowska, J. (2010). Pisarze w zwierzyńcu. Poznań: Wydawnictwo Poznańskie.

Barcz, A., Dąbrowska, M. (red.). (2014). Zwierzęta, gender i kultura. Perspektywa ekologiczna, etyczna i krytyczna. Lublin: E-naukowiec.

Barcz, A., Łagodzka, D. (red.). (2015). Zwierzęta $i$ ich ludzie. Zmierzch antropocentrycznego paradygmatu. Warszawa: Wydawnictwo IBL PAN.

Barcz, A. (2016). Realizm ekologiczny. Od ekokrytyki do zookrytyki w literaturze. Katowice: WN Śląsk.

Barry, P. (2017). Ekokrytyka (M. Białodzia, M. Furmaniak, R. Korzeń i in., tłum.). W: P. Czapliński, J. B. Bednarek, D. Gostyński (red.), Literatura i jej natury. Przewodnik ekokrytyczny dla nauczycieli i uczniów szkót średnich (s. 21-36). Poznań: Rys. (wyd. oryg. 2002).

Bateson, G. (1996). Umyst i przyroda. Jedność konieczna (A. Tanalska-Dulęba, tłum.). Warszawa: PIW. (wyd. oryg. 1979).

Bendyk, E. (2015). Świat bez węgla. W: M. Sutowski (red.), Polski węgiel. Warszawa: Wydawnictwo Krytyki Politycznej.

Bińczyk, E. (2018). Epoka człowieka. Retoryka i marazm antropocenu. Warszawa: WN PWN.

Black, R. W. (1994). What we talk about when we talk about ecocriticism. Referat wygłoszony podczas spotkania Western Literature Association Meeting, Salt Lake City, UT. Pobrane z: https://www.asle.org/wp-content/uploads/ASLE_Primer_DefiningEcocrit.pdf.

Chmielewski, D. (2018). Miasto Złotej. Warszawa: Tadam.

Czapliński, P. (2017). Ekokrytyka. W: P. Czapliński, J. B. Bednarek, D. Gostyński (red.), Literatura i jej natury. Przewodnik ekokrytyczny dla nauczycieli i uczniów szkót średnich (s. 182-184). Poznań: Rys.

Czochralska, B. (2001). Spotkanie z innym człowiekiem. W: A. Papuziński, Z. Hull (red.), Wokót eko-filozofii. Księga jubileuszowa ofiarowana profesorowi Henrykowi 
Skolimowskiemu dla uczczenia siedemdziesięciolecia urodzin (s. 25-30). Bydgoszcz: Wydawnictwo Akademii Bydgoskiej im. Kazimierza Wielkiego.

Domańska, E. (2013). Humanistyka ekologiczna. Teksty Drugie, 1-2, 13-32.

Dubas, E. (2006). Samotność - uniwersalny „temat” życia ludzkiego i wychowania. W: P. Domeracki, W. Tyburski (red.), Zrozumieć samotność. Studium interdyscyplinarne (s. 329-349). Toruń: WN UMK.

Ekman, S. (2018). Urban fantasy - literatura Niewidocznego (M. Wąsowicz, tłum.). Creatio Fantastica, 1(58), 7-27. https://doi.org/10.5281/zenodo.1419517. (wyd. oryg. 2016).

Eliade, M. (1999). Sacrum i profanum. O istocie religijności (R. Reszke, tłum.). Warszawa: Wydawnictwo KR. (wyd. oryg. 1957).

Fiedorczuk, J. (2015). Cyborg w ogrodzie. Wprowadzenie do ekokrytyki. Gdańsk: WN Katedra.

Freud, Z. (1997). Niesamowite. W: Pisma psychologiczne (R. Reszke, tłum., s. 233-262). Warszawa: KR. (wyd. oryg. 1919).

Gajda, R., Szcześniak, N. (2018). Archistorie. Jak odkrywać przestrzeń miast?. Kraków: Znak.

Gajda, R., Szcześniak, N. (2015-2018). Architecture is a good idea. Pobrane z: https:// goodidea.archi.

Gemra, A. (2006). Twarz pod maską. Kilka uwag na marginesie wybranych ikon grozy. W: J. Kolbuszewski (red.), Literatura i wyobraźnia. Prace ofiarowane profesorowi Tadeuszowi Żabskiemu (s. 501-510). Wrocław: Agencja Wydawnicza a linea.

Gralewicz-Wolny, I. (2015). „Tę książkę wymyślił pies”. Ferdynand Wspaniały Ludwika Jerzego Kerna jako lektura ekokrytyczna. W: B. Niesporek-Szamburska, M. Wójcik-Dudek, A. Zok-Smoła (red.), (Przed)szkolne spotkania z lektura (s. 315-324). Katowice: Wydawnictwo UŚ.

Has-Tokarz, A. (2006). Horror architektoniczny. O fizycznym i semantycznym statusie przestrzeni w literaturze i filmie grozy. W: J. Kolbuszewski (red.), Literatura i wyobraźnia. Prace ofiarowane profesorowi Tadeuszowi Żabskiemu (s. 465-485). Wrocław: Agencja Wydawnicza a linea.

Has-Tokarz, A. (2010). Horror w literaturze współczesnej i filmie. Lublin: Wydawnictwo UMCS.

Has-Tokarz, A. (2015). Zwierzę-zabójca jako motyw literacki i filmowy. Rzecz o horrorze eko(logiczym). W: E. Łoch, A. Trześniewska, D. Piechota (red.), Emancypacja zwierzat? (s. 88-103). Lublin: LTN.

Jarzyna, A. (2019). Post-koiné. Studia o nieantropocentrycznych językach (poetyckich). Łódź: Wydawnictwo UŁ.

Kopczyński, K., Skoczylas, J. (2008). Krajobraz przyrodniczy i kulturowy. Próba ujęcia interdyscyplinarnego. Poznań: WN UAM. 
Krupiński, P. (2016). „Dlaczego gęsi krzyczały?”. Zwierzęta i Zagłada w literaturze polskiej XX i XXI wieku. Warszawa: IBL PAN.

Landsberg, A. (2012). Pamięć protetyczna (M. Szewczyk, tłum.). W: I. Kurz, P. Kwiatkowska, Ł. Zaremba (red.), Antropologia kultury wizualnej (s. 690-698). Warszawa: Wydawnictwa UW. (wyd. oryg. 2004).

Latour, B. (2014). Anthropology at the time of the Anthropocene - a personal view of what is to be studied. Referat wygłoszony podczas dorocznego spotkania American Association of Anthropologists, Waszyngton, DC. Pobrane z: http://www.bruno-latour.fr/sites/default/files/139-AAA-Washington.pdf.

Maliszewski, K. (2015). Pedagogika na pograniczu światów. Eseje z cyklu „Medium Mundi". Katowice: Wydawnictwo UŚ.

Mik, A., Pokora, P., Skowera, M. (red.). (2016). Czytanie menażerii. Zwierzęta w literaturze dziecięcej, młodzieżowej i fantastycznej. Warszawa: Wydawnictwo SBP.

Muszyński, H. (1977). Zarys teorii wychowania. Warszawa: WN PWN.

Mytych-Forajter, B. (2015). Doktor Dolittle i jego zwierzęta - lektura ekokrytyczna. W: B. Niesporek-Szamburska, M. Wójcik-Dudek, A. Zok-Smoła (red.), (Przed)szkolne spotkania z lektura (s. 325-334). Katowice: Wydawnictwo UŚ.

Norberg-Schultz, Ch. (1971). Existence, space and architecture. London, New York, NY: Studio Vista, Praeger.

Oreskes, N., Conway, E. (2017). Upadek cywilizacji zachodniej. Spojrzenie z przyszłości (E. Bińczyk, J. Gużyński, K. Tarkowski, tłum.). Warszawa: WN PWN. (wyd. oryg. 2014).

Oworuszko, M. (2015a). Walenty i spółka. Warszawa: Mobuki.

Oworuszko, M. (2015b). Walenty i spółka ruszaja w świat. Warszawa: Mobuki.

Oworuszko, M. (2016a). Walenty i spótka buduja piramidę. Warszawa: Mobuki.

Oworuszko, M. (2016b). Walenty i spółka szukaja witamin. Warszawa: Mobuki.

Oworuszko, M. (2017). Walenty i spółka podróżują w czasie. Warszawa: Mobuki.

Oworuszko, M. (2018). Walenty i spółka znajduja mapę. Warszawa: Mobuki.

Oworuszko, M. (2019). Walenty i spółka organizują olimpiadę. Warszawa: Mobuki.

Pacewicz, P. (2020, 19 stycznia). RPO: Uczcie o zmianach klimatu! MEN: Uczymy o dziurze ozonowej i korozji. OKO: Co to ma do rzeczy?. Pobrane z: https:// oko.press/rpo-uczcie-o-zmianach-klimatu-men-uczymy-o-dziurze-ozonowejoko-press-analizuje-szkolny-program/.

Popkiewicz, P., Kardaś, A., Malinowski, S. (2019). Nauka o klimacie. Obserwacje zmian klimatu teraz i w przeszłości, mechanizmy działania systemu klimatycznego, dawne zmiany klimatu - co, kiedy, jak i dlaczego, obecna zmiana klimatu - obserwacje, przyczyny, przyszła zmiana klimatu - dokąd zmierzamy, klimatyczne kontrowersje. Katowice: Sonia Draga.

Rąbkowska, E. (2017). Zwierzęta i ich dzieci - poznanie, empatia, etyka. Perspektywa ekokrytyczna w literaturze dla dzieci i młodzieży. W: P. Czapliński, J. B. Bednarek, 
D. Gostyński (red.), Literatura i jej natury. Przewodnik ekokrytyczny dla nauczycieli i uczniów szkół średnich (s. 37-48). Poznań: Rys.

Ruskin, J. (1849). The seven lamps of architecture. London: The Waverley Book Company.

Scruton, R. (2017). Zielona filozofia. Jak poważnie myśleć o naszej planecie (J. Grzegorczyk, R. P. Wierzchosławski, tłum.). Poznań: Zysk i S-ka. (wyd. oryg. 2012).

Skolimowski, H., Górecki, J. K. (2003). Zielone oko kosmosu. Wokół ekofilozofii w rozmowach i esejach. Wrocław: Atla 2.

Slany, K. (2016). Groza w literaturze dziecięcej. Od Grimmów do Gaimana. Kraków: WN UP.

Strękowska-Zaremba, M. (2017). Dom nie z tej ziemi. Warszawa: Nasza Księgarnia.

Tabaszewska, J. (2010). Jedna przyroda czy przyrody alternatywne? O pojmowaniu i obrazach przyrody w polskiej poezji. Kraków: TAiWPN Universitas.

Wilson, E. O. (2017). Pół Ziemi. Walka naszej planety o życie (B. Baran, tłum.). Warszawa: Aletheia. (wyd. oryg. 2016).

Wyka, A. (1996). Próba komentarza. W: G. Bateson, Umyst i przyroda. Jedność konieczna (A. Tanalska-Dulęba, tłum., s. 305-315). Warszawa: PIW.

Zajączkowska, U. (2019). Patyki, badyle. Warszawa: Marginesy. 